\title{
Revisiting the Concept of Freedom in George Orwell's $A$ Hanging and Shooting an Elephant: A Postcolonial Perspective \\ https://doi.org/10.33806/ijaes2000.21.1.8
}

\author{
Hussein Zeidanin and Abdullah Shehabat \\ Tafila Technical University, Jordan
}

\begin{abstract}
George Orwell's Shooting an Elephant and A Hanging are representative of an essentialist colonial discourse that widens gaps and nourishes conflicts between the west and other civilizations and cultures. The research paper argues that the image of the white man as an independent, free, self-determining and self-initiated subject is shattered by an uncritical acquiescence to the authority of the empire and the native crowds. Recognizing ironic freedom as grasped from the standpoints of first person narrators is essential for determining who is really free: the Burmese or their colonizer. Edward Said's metaphors of the potentate and traveller, which respectively signify domination and acculturation, lay the ground upon which the narrator in each of Orwell's stories is characterized. The narrators' physical and emotional detachment from Burma parallels their unbreakable ideological attachment to the empire. This parallelism unveils a desire for dominion and control and a suppressed fear of humility or servility. Yet, their authority and command as potentates are disrupted by the restrictions the empire, as well as the natives, place on their freedom.
\end{abstract}

Keywords: empire, freedom, Orwell, post-colonialism, potentate, traveller

\section{Introduction}

The current study investigates the ironic use of freedom in Shooting an Elephant and A Hanging by George Orwell (1903 - 1950). The narrators' sense of freedom together with that of the natives is questioned based on Edward Said's conception of the potentate and the migrant or traveller. The potentate authoritatively observes others in his domain "with detachment and mastery" (Said 1994: 7). The traveller, however, depends more on the physical activity than on power or authority as one willingly travels into different places. Unlike the potentate, who usually guards and defends the frontiers of one place, the traveller "crosses over, traverses territory, and abandons fixed positions, all the time" (Said 1994: 17). The model of freedom, Said upheld, was that of the traveller because it helps "discover and travel among other selves, other identities, other varieties of the human adventure" (Said 1994: 17). The model of traveller Said adopted conforms to his conception of hybridity as "the creation of new transcultural forms within the contact zone produced by colonization" (Ashcroft, Griffiths and Tiffin 2000: 108). The narrators, the study argues, act and speak more like potentates than travellers. Their voyages to Burma neither free their will nor hybridize their cultural identities; rather they result in further confinement and alienation. Instead of freeing themselves from imperial tutelage, they ironically fall preys to its shackles. 
The study approaches Orwell's stories from the perspective of the postcolonial theory to unveil the hierarchies and power relations embedded in the colonial discourse. Said's conception of freedom and his models of the potentate and the traveller are of a great significance for understanding the identity of the narrators, who are represented as typical colonial subjects plagued with such an ethnocentric stereotype as the supremacy of the white race and culture. The narrators' stereotypical representation of the native culture and people unfold their inability to break free from the colonial ideology for which they are prisoners. The ironic self-awareness, which the narrator in each story proceeds from, reveals how each becomes well-aware of his powerlessness and constrained freedom and command at the first confrontation with the natives. Such an awareness, which places the colonized in a more hegemonic position, deconstructs the binary oppositions established by the colonial discourse and casts doubt upon the authority, primacy and freedom of imperial subjects. The pressing questions the study addresses are: to what extent are the narrators free? And do they manage to free themselves from the colonial views and assumptions?

\subsection{Contributions of the study}

The current study primarily focuses on whether colonial agents are really free and self-determined. Said's conception of freedom is the means through which the verbal and physical responses of characters are analysed in order to better understand the implications of the two stories. The findings attained support our argument: that the colonial ideology enslaves and suppresses its representatives, i.e., the narrators, as much as it does the colonized people. The study finds that neither the colonized nor the colonizer manages to free themselves from the shackles and tutelage of imperialism.

\section{Literature review}

\subsection{Critical Reception of Orwell's Works}

Two critical trends toward Orwell can be identified: critics appreciating Orwell's novels as well as his essays and critics dismissing him as a novelist but highly acknowledging him as a journalist and documentary writer (Saunders 2016). The critical attention to Orwell's work has steadily continued since his death.

However, the existence of a pervasive literary persona in Orwell's writing renders it pseudo-autobiographical (Woodcock 2014). Most studies conducted on Orwell since his death in 1950 are biographical in character. These studies are classified into parabiographies with a polemical tone and a small and recent body of work that is impersonal and critical in nature. Both the pen name, George Orwell, and the personal name, Eric Blair, lived together "like brilliant son and modest father, George Orwell a public personality and Eric Blair a secretive hidden being, and a mortal being" (George Woodcock 2014: 524). If Orwell completely denied the private self, it would be a kind of parricide. The earliest biographical books on Orwell were written between 1954 and 1966 by his own friends, e.g., John Atkins (1954), Christopher Hollis (1956) and Richard Rees 
(1961). Each of the former biographers tackled a facet of Orwell: essential conservative, left-wing socialist and anarchist.

In addition, a number of prominent American critics such as Richard J. Voorhees (1961), Robert A. Lee (1969), and Keith Alldritt (1969) published critical books on Orwell's works. The American critics contended that Orwell's novels should be read as fiction but not distorted documentaries. In their works, Orwell is represented as a critic of socialism whose political attitudes transformed from anarchism to socialism and from radical patriotism of the war years to the idealism and pessimism dominating the last years of his life. Orwell also turned from writing realistic novels and prose documentaries marred by topicality and didacticism to writing satirical fantasies of Animal Farm and Nineteen Eighty-Four (Zwerdling 1974). Orwell is further introduced as a dedicated puritan glorifying the freestanding individual though he never gave any hint that his works were religious in intent (Sandison 1986).

\subsection{Overview of scholar's viewpoints of the research questions}

Reviewing the literature on Orwell's Shooting an Elephant and A Hanging yielded insightful interpretations of the narrators' viewpoints and attitudes. Shooting an Elephant is an autobiographical story through which George Orwell reflects upon his mission as an imperial police officer of a town in Burma and his in-betweenness with reference to imperialism and cultural identity (Oguz 2016). Orwell suggests that imperialism equally debases, destroys and alienates natives as well as colonizers. Orwell's notion of "Fixity in the construction of otherness" (Oguz 2016: 170) is a major shortcoming Orwell attaches to imperialism. The narrator in the story confronts a dilemma whether to sympathize with the Burmese or to act according to the imperial rules. Such hybridized thoughts and feelings result in his in-betweenness which is manifested by his critique of the imperial system, his attempts to understand the natives and his feeling of compassion for them. He realizes that cultural differences, social injustices and unequal conditions are to blame for the hatred the natives harboured towards imperial officers. The formation of an ambivalent cultural identity is "a result of the negation and then corruption and transformation of the self-affected by its relation with other" (Oguz 2016: 171). He accordingly develops an ambivalent identity for being "trapped and hybridized in thought in an ambivalent place between his culture and the natives' culture" (Oguz 2016: 167). His resolution to shoot the elephant can be interpreted as a response to the demand and expectations of the natives, "cultural expectations determine people's behavioural reactions and responses to other person's actions because culture has a place in the individual positions, inter subjective and collective experiences" (Oguz 2016: 167). The person in a postcolonial society, like Burma, finds himself in an in-between position and assumes a hybridized ambivalent identity which belongs to nowhere.

Orwell is popularly proclaimed as an anti-imperialist writer though it is alleged that the seeds of imperialism are found under the mask of anti-imperialism. In Shooting an Elephant, Orwell cannot be read as 
anti-imperialist because he writes from the perspective of the English but not the Burmese. He neither appreciates Burmese aspirations for freedom and independence nor genuinely represents their native culture and traditions. Instead, he primarily explores "a subjective truth that has significance only for the imperialist" (Alam 2006: 59). His writing offers a western interpretation of the imperial situation which belittles the "detrimental effects of the British Raj on Burmese economy and culture" (Alam 2006: 58) and enlarges "the ironic plight of the imperialist; he is a victim of imperialism, a captive of its by-products, of isolation and moral corruption, and of its code of behaviour" (Alam 2006: 59). The existentialist opposition between the west and other civilizations and cultures as represented in the story unveils Orwell's imperial conscience; while the west is portrayed as being the essential, other civilizations the inessential. The story disregards the colonial conditions of Burma as a colony and the Burmese as real human beings, who are represented as "grotesquely evil and preposterously innocent to merit any attention" (Alam 2006: 59). In addition, Orwell does not show any sympathy or compassion for the colonized. Burma conceded its sovereignty and autonomy to the British Empire of which it became a province or a colony but not an independent country. Thus, Burma, in Orwell's conception, does not really exist but in his writing. The story introduces Orwell as a westerner believing in his racial superiority, "how a man can become corrupted by his national and social pride, which makes him believe that he is better than other people" (Alam 2006: 59).

Postcolonial critics, particularly Said, reflect upon the relationship between the portrayer or westerner and the portrayed or the Easterner. In an orientalist work, the self is the occident, the dominant, the ruler, the creator, whereas the other is the dominated, the coloured, the orient, the ruled and the fabricated. One common characteristic of orientalist works is duplicity, which denotes such conflicting feelings as "to sympathize with the natives, to pity for their wretchedness, to eulogize their periphery customs and lifestyle, while under other circumstances to hate them and treat them as less humane which must be ruled by their western masters" (Ghaforian and Gholi, 2015: 1362). One duplicity in Shooting an Elephant is related to the narrator, who is torn between resenting the oppressor and sympathizing with the oppressed or the victim. Another duplicity is evident in his recognition of the evil of imperialism and celebration of the British Empire that he prefers to other empires such as Japan, Italy or Russia. A third duplicity is revealed by his expression of sympathy and joy for the Burman, whom the elephant kills. The risk the elephant poses to the community "gave him an excuse to free himself from punishment" when shooting it (Ghaforian and Gholi 2015: 1366).

The second short story, A Hanging, articulates Orwell's suppressed feelings and thoughts towards the morality and ethics of capital punishment, which is brought to the forefront by the arrangements the British authorities made to hang a Burmese prisoner. Then Orwell proceeds to describe the animal-like conditions of the prison cells. Amid the heartlessness of the superintendent and warders, Orwell 
presents the dog to signify " a humanity that is untainted, the only figure to show kindness to the prisoner. The dog is the repressed urge to acknowledge the inhumane, the crack in the glass, and the moment of realization" (Prescott: 2016: 9). The dog is also a significant symbol for interruption and breach in formality; it is the device through which Orwell "can skilfully channel his own feelings and conscience without articulating them himself" (Prescott 2016: 9).

Reading narrative events in A Hanging from the perspective of the literary theory of new criticism helps identify substantial ironies, mostly alluding to the crucifixion of Jesus Christ as revealed in the gospel. The nine ironies identified in the story are as follows: the prisoner was submissive, not revolting, posing no harm, but precaution against his escape is very strict and heavy; fellow human beings extend no kindness, whereas an animal offers solace; avoiding trivial annoyance, while fatality is at hand; the convict has died but the superintendent assured them he was alright; a doctor who is supposed to know about life and death pulls the prisoner's legs to assure death; warders plead to be understood and pitied by a dreaded convict; meals are served after the execution; people laugh for a reason they do not know; people are psychologically terrorized by their deliberate infliction of the prisoner (Nababan 2010: 54 - 56). These ironies are closely related to our reading of the story and investigation of the research questions as they reveal the cowardice, inhumanity, fear and apathy of colonial subjects when confronting or interacting with the colonized.

\section{Discussion}

This section distinguishes between travelling intellectual and intellectual potentate. Intellectual potentates internalize the nationalist ideals of the homogeneity and hierarchy of cultures, races and ethnicities, which they usually cannot be free from. They confine themselves to a single dominant culture and resist any attempts of heterogenization and hybridization for fear of difference and otherness. They, therefore, tend to exclude, subordinate and dehumanize people of different races and ethnicities. Traveling intellectuals, however, disprove those ideals and alternately advocate the belief that "all cultures and societies today are intermixed. No country on earth is made up of homogenous natives; each has its immigrants, its internal Others; and each society ... is a hybrid" (Said 1994: 10). Cultures for them do not exist in isolation; and the world is "made up of numerous identities interacting, sometimes harmoniously, sometimes antithetically" (Said 1994: 16). The textual and contextual analysis, the study conducts, assumes that the narrator in shooting an Elephant and the narrator in A Hanging, act more as intellectual potentates than travelling intellectuals. However, the constraints placed one their freedom and authority by the British Empire and the native crowd shatter their image as independent, free, self-determining and self-initiated subjects. On that basis, Imperial authority and freedom are mere illusions that are shattered at the first encounter with the colonized. 


\subsection{Illusion of imperial authority}

The narrator in Shooting an Elephant comes to Burma as a potentate but not as a traveller because Burma was a colony whose domain and people were supposed to be protected and defended by the British Empire. He seeks to establish the authority and command of the British Empire through his protection and guardianship of Burma and the Burmese. Yet, he does that with a sense of detachment and mastery. The duality of the west and other cultures and civilizations, which he maintains, helps him to be as detached as possible from the Burmese. This analytical reading of the narrator's imperialist attitudes resonates the contention that "it is the imperialist shame and indigenous guilt that sustain the relationships of dominance and subservient in colonial Burma" (Malreddy 2019: 1). He, for instance, compares his civility to the savageness of the natives, his whiteness to their yellowness, his audacity to their affright, and his superiority to their inferiority. He denounces their anti-European sentiments and showcases their yellow faces, their fright from the charged elephant, and most importantly their racial and cultural differences. He discloses that the natives were too coward to "raise a riot" (Orwell 1968: 23), but whenever it seemed safe, they would insult and jeer at Europeans. That the narrator only uses collective rather than proper nouns such as the "crowd", "sea of yellow faces" (Orwell 1968: 26) and "Burmese" (Orwell 1968: 27) to refer to the people of Burma is another device to perpetuate his detachment from the colonized and the colonial reality.

As a potentate, the narrator has to lead and command with mastery, firmness and confidence. The word sahib, an English word of Arabic origin signifying mister or master in Indian Sub-continent, in the story is used in the sense of a potentate. He reveals that he had to act like a sahib, who "has got to appear resolute, to know his own mind and do definite things" (Orwell 1968: 26). It is the incident of the elephant that puts his command and leadership at stake. His subsequent actions, choices, decisions and attitudes manifest a serious concern about his authority and image as a sahib. Terrified by the humiliating prospect of becoming a fool, he reconsiders the natives' claims which he has a reasonable ground to distrust. His questioning of the people as to where the elephant has gone proves fruitless, a finding he supports with his bigoted preconceived belief that is "invariably the case in the East; a story always sounds clear enough at a distance, but the nearer you get to the scene of events, the vaguer it becomes" (Orwell 1968: 24). Though he eventually realizes that "the whole story was a pack of lies" (Orwell 1968: 24), he dares not stop chasing the elephant considering the intolerable roaring laughter of the natives. In his confrontation with the elephant, he places his survival in one balancing scale and his public respect on the other. He ponders over what danger a charged elephant would cause, whether his small rifle would be able to kill an elephant, and whether his feet would sink into the soft, muddy ground. The fragilities of his physical prowess as well as his weapon in such a fatal contest are less frightening to him than the awaiting humiliation and laughter as grasped from his recognition that if the rifle mishit the elephant, he "should have about as much chance as a toad under a steam-roller" (Orwell 1968: 24). Yet, his persistent quest of glory 
and pride amid the natives' shouts and the wreckage of the huts the elephant destroyed tilts the balance in favour of his public respect that has become at stake. Under such conditions, he resolutely shoots three bullets at the elephant, two at the earhole and one at the heart, to demonstrate his mastery and prowess.

The potentate or sahib model, upon which the character of the narrator in Shooting an Elephant is analysed, can be extended to the character of the narrator in A Hanging. As a magistrate for the British Empire, he has to appear superior and relentlessly resolute and authoritative. The interplay of the third person pronouns and first person pronouns and of their corresponding roles and terms of address in the story reflects the relation between the social rank and cultural identity. When referring to the British, either first-person pronouns or the police rank like the superintendent is used, but third person pronouns (i.e. they), proper nouns (i.e. Francis), collective nouns (i.e. warders and men) or common nouns (i.e. prisoner and hangman) are used to refer to the natives. The variety of the pronouns and terms of address used suggests a hierarchy of power relations between the British and the natives. In a jail community, a message passes from a supreme authority or sender (the superintendent and British magistrates) to a receiver (Burmese warders) who accordingly acts. As a director of the jail, the superintendent orders to commence the hanging procession according to which six warders got a prisoner ready for the gallows, "two of them stood by with rifles and fixed bayonets, while the others handcuffed him, passed a chain through his handcuffs and fixed it to their belts, and lashed his arms tight to his sides" (Orwell 1968: 19). In such a community, there is no place for dialogue or negotiation but oppression and suppression. This explains why warders cannot oppose or reject the orders given to them; why the hangman, a Burmese, has to greet the superintendent and the British magistrates with "a servile crouch" (Orwell 1968: 21) as they entered; and why Francis, a Burmese jailer, flatteringly tells the superintendent "well, sir, all passed off with the utmost satisfactoriness. It all finished - flick! like that. It not always so - oah, no!" (Orwell 1968: 22). Francis goes on to mock this prisoner and other prisoners for their refractory responses and feelings of fear and terror when taken out of their cells to the gallows. Even the story's last scene, in which the superintendent treats his British fellows together with the native jailers to a drink, cannot be taken as a token of amicability, geniality or equality; rather it can be viewed as a favour bestowed by the British master upon his Burmese slaves, who are expected to be so appreciative and grateful to their genial master.

The narrator's enunciated sense of authority and superiority along with his recognition of the inferiority of the natives is contrarily undermined by his criticism of the British Empire. In fact, he sounds as resolute in his condemnation of the empire as the narrator in Shooting an Elephant. He, on one hand, protests at the inhuman conditions, particularly maltreatment, congestion, shortage of food and infringement of their basic rights under which Burmese prisoners were being kept in the British jails in Burma. He expounds that the cells are as cramped as small animal cages and are bare except for a bed and a pot of drinking water; inmates are squatting inside and have to squat in long rows with a small pan in 
hand to get food; the jail yard is surrounded with high walls through which a dim light is diffracted.

On the other hand, the narrator condemns the practice of hanging in the British colonies including Burma. He considers prisoners, whether in Burma or elsewhere, equal to their British jailers in terms of humanity as evidenced in his abrupt realization "what it means to destroy a healthy, conscious man... He and we were a party of men walking together, seeing, hearing, feeling, understanding the same world "(Orwell 1968: 20). He thinks it is an unspeakable crime to cut someone's life short "when it is in full tide" (Orwell 1968: 20). The prisoner is just as alive as anyone else; the organs of his body such as eyes, ears, brain, belly and nails are fully at work. The moment when he steps aside to avoid a puddle on his path to the gallows clearly shows that his eyes can see and his brain can still remember, foresee and reason. The right to life is, therefore, so sacrosanct that it cannot be violated for whatever considerations or justifications.

What also mitigates the narrator's sense of superiority is the homage he pays to the intrepidity of the hanged prisoner. Contrary to the flattering claims of Francis, he relates that the prisoner was neither scared nor afraid. He walked quite steadily; and his feet were stable enough to print "themselves on the wet gravel" (Orwell 1968: 19). Though his arms were bound and his shoulders were gripped, he was able to step "slightly aside to avoid the puddle on the path" (Orwell 1968: 20). The prisoner showed no signs of regret or apology for what he had done to deserve such a punishment. His voice never shook with fear or terror; the fervent prayers he cried out to Ram (his god) while on the gallows were "not urgent and fearful like a prayer or a cry for help, but steady, rhythmical, almost like the tolling of a bell"(Orwell 1968: 21). The prisoner's cries seemed to cause pangs of remorse for the British and the natives alike, "everyone had changed colour. The Indians had gone grey like bad coffee, and one or two of the bayonets were wavering. The same thought was in all our minds: oh, kill him quickly, get it over, stop that abominable noise!" (Orwell 1968: 21) Tormented with the prisoner's intolerable and unfaltering cries, the narrator wishes that he would be immediately hanged in order not to hear his cries anymore.

\subsection{Illusion of freedom}

What is so ironic and disruptive of the narrator's authority as a potentate in Shooting an Elephant is his constrained freedom that shatters the long-established image of the colonizer as a free, willing and independent individual. Neither his resolution to shoot the elephant nor his combat for the British Empire in the East emanates from a free will. In a striking but enlightening epiphany, he realizes that he, as a white man armed with a gun, is "standing in front of the unarmed native crowd-seemingly the leading actor of the piece; but in reality I was only an absurd puppet pushed to and fro by the will of those yellow faces behind" (Orwell 1968: 26). Considering the numerous armies sent and the large stock of ammunition shipped to the battle fronts in colonies, the white man is supposed to be in a hegemonic position to control and lead the colonized people; nonetheless, he appears to be merely a puppet whose strings are controlled and pulled by the 
yellow-face natives. The narrator, therefore, projects his feelings of guilt for killing a peaceful elephant on the native crowds. He unwillingly shoots the elephant to impress the Burmese and "avoid looking a fool" (Orwell 1968: 28). In like manner, he maintains "when the white man turns tyrant it is his own freedom that he destroys" (Orwell 1968: 26). Tyranny, for him, seems to be an emergent attribute of the white man but a fundamental attribute of the colonized or the natives because the white man's discharge of violence is stimulated by the natives when they succeed to strip his freedom and willingness away. This can be understood as an attempt to justify shooting the elephant and to project his own guilt and tyranny on the natives.

In another striking epiphany, the narrator admits that he bitterly hates the British Empire, which he has served and defended, for its "dirty work" (Orwell 1968: 23). Among the atrocities and transgressions of the British Empire against the Burmese, which he remorsefully condemns, are locking the wretched prisoners and long-term convicts in stinking cages, scarring their buttocks with bamboo whips, and terrifying them with threats and violence. His suppressed anticolonial feelings and thoughts are theoretically and secretly but not freely released for his fear of the empire. The ambivalent feelings and ideals he holds are a manifestation of conscious deception, which Orwell conceived as "doublethink, implying the capacity of an individual to hold simultaneously two antithetical ideas in his mind" (Safaei 2020: 162). They also heighten the conflict between his obligations as a soldier and his freedom as substantiated by his disclosure that "with one part of my mind I thought of the British Raj as an unbreakable tyranny; with another part I thought that the greatest joy in the world would be to drive a bayonet into a Buddhist priest's guts" (Orwell 1968: 23). However, the shackles of his imperial tutelage seem to be too strong to be broken free from. He rationalizes that unbreakable confinement with an accentuation that "I was young and ill-educated and I had had to think out my problems in the utter silence that is imposed on every Englishman in the East" (Orwell 1968: 23). The justifications he relates put him in the same basket with other colonial soldiers, who are deemed helpless and powerless victims of imperialism. Disadvantaged by his young age and ill-education along with his fear of criminalization, he silently contemplates over the whole project of imperialism. This contemplation unfortunately yields a flawed finding that the British Empire is "a great deal better than the younger empires that are going to supplant it" (Orwell 1968: 23). The controversial finding, he comes up with, demonstrates his inability to free himself from the imperial authority that he is irresistibly succumbing to.

In A Hanging, the narrator expresses homage to his other foil, the dog, for his prowess and audacity. The dog in the story signifies freedom from all kinds of restrictions and constraints. The superintendent and warders vainly attempt to stop him from barking. It takes them minutes before anyone manages to catch and secure him through the collar. Yet, the dog keeps barking; he continues "straining and whimpering" (Orwell 1968: 20) exactly like the prisoner. Only after the prisoner is hanged does the narrator let go of the dog who "galloped immediately to the back of the gallows; but when it got there it stopped short, barked, and then 
retreated into a corner of the yard, where it stood among the weeds, looking timorously out at us" (Orwell 1968: 21). The dog is portrayed as being more human and audacious than human beings despite the pejorative polemical labels used to designate him, i.e., "bloody brute" (Orwell 1968: 20). The dog sounds as a firm opponent to hanging the prisoner. The growls, howls and moans the dog produces arouse as much remorse as the cries of the prisoner, if not more, in the British and Burmese jailers including the narrator.

The freedom through which the narrator confesses his anticolonial attitudes to readers is restricted by his concerns about his reputation and authority as a potentate in reality. Nowhere in the story does he object to or oppose the oppressive and subordinating practices against the Burmese prisoners. He often sounds to be more bound by the imperial authority than by his free will. Like in Shooting an Elephant, the narrator determines to suppress his anticolonial passions in order not to look indeterminate and uncertain. The contradictions between what he feels, what he confesses and what he does reveal an unresolved conflict, whether to be more committed and dutiful to the British Empire or to one's integrity. Fearing to lose his authority and commission, he waives his integrity and free will for the empire's sake. This accounts for the enormous relief he feels following the hanging, "one felt an impulse to sing, to break into a run, to snigger. All at once everyone began chattering gaily" (Orwell 1968: 22).

\section{Conclusion}

The study concludes that the narrator in Shooting an Elephant and the narrator in A Hanging are doubly repressed by the imperial rule as well as the native crowd. They diabolize the British Empire and feel remorseful for its atrocities and transgressions. They, likewise, demonize the natives for their apathy, savageness and cruelty. Yet, they evade any confrontation with the empire or the natives for a fear of humility and punishment. The constraints placed on their freedoms disrupt their authority and command as a sahib or potentate, whom Said envisages as a free authoritative subject. Their authority as agents of the British Empire collides with that of the native crowd to which they eventually submit. Their critique of the British Empire, the study finds, redresses no perpetrated grievances and injustices. 
Hussein H. Zeidanin

English Language and Literature Department

College of Art

Tafila Technical University, Jordan

ORCID Number: 0000-0003-4433-0178

Email: husseino_z@yahoo.com

Abdullah K. Shehabat

English Language and Literature Department

College of Art

Tafila Technical University, Jordan

ORCID Number: 0000-0002-1782-4589

Email: abdullahshehabat@gmail.com

\section{References}

Alam, Mohammed (2006). 'Orwell's Shooting an Elephant: Reflections on Imperialism and Neoimperialism'. IIUC Studies. 3: 55 - 62.

Ashcroft, Bill, Gareth Griffiths and Helen Tiffin. (2000). Postcolonial Studies: The Key Concepts. Taylor \& Francis Group: Routledge.

Ghaforian, Ahmad and Ahmad Gholi. (2015). 'A Postcolonial Reading of George Orwell's Shooting an Elephant with Special Reference to Edward Said's Orientalism and Binary of the Self and the Other'. Theory and Practice in Language Studies. 5 (7): 1361 - 1367.

Malreddy, P. Kumar. (2019). 'Imperialist shame and indigenous guilt: George Orwell's writings on Burma'. European Journal of English Studies. 23(3): $311-325$.

Nababan, Mangatur. (2010). 'Irony in A Hanging'. A Journal of Language Culture and Education 4 (1): 52 -58.

Oguz, Ayla. (2016). 'Cultural Identity in George Orwell's Shooting an Elephant'. IXth European Conference on Social and Behavioural Sciences (IASSR-Paris).

Orwell, George. (1968). Shooting an Elephant and other Essays. Delphine Lettau, Howard Ross \& the online Distributed Proofreaders.

Prescott, Nadia. (2016). Literary Journalism Analysis of George Orwell's 'A Hanging' and 'Shooting an Elephant'. Unpublished BA Thesis, University of Buckingham, England.

Safaei, Mohammad. (2020). 'The Face of Dictatorship in George Orwell's Nineteen Eighty-Four, Gabriel Garcia Marquez's The Autumn of the Patriarch, and Mario Vargas Llosa's The Feast of the Goat'. International Journal of Arabic-English Studies (IJAES). 20(2): 149 - 168.

Said, Edward. (1994). 'Identity, Authority, and Freedom: The Potentate and the Traveller'. Boundary 221 (3): 1 - 18. 
Sandison, Alan. (1986). George Orwell After "1984". UK: Palgrave Macmillan. Saunders, Loraine. (2016). The Unsung Artistry of George Orwell: The Novels from Burmese Days to Nineteen Eighty-Four. Routledge: Taylor and Francis Group.

Woodcock, George. (1975). 'Orwell, Orwell and the Critics'. The Sewanee Review, 83 (3): 524-536.

Zwerdling, Alex. (1974). Orwell and the Left. New Haven: Yale University Press. 